\title{
Evaluation of IDM Components for Management of Tomato Powdery Mildew under Protected Cultivation
}

\author{
Arushi, A.B. Malannavar and D.K. Banyal* \\ Department of Plant Pathology, CSK HPKV, Palampur-176062, HP, India \\ *Corresponding author
}

\begin{tabular}{|l|}
\hline K e y w or d s \\
Tomato, Powdery \\
mildew, Oidium \\
neolycopersici, \\
Bioagents, \\
Botanicals, \\
Fungicides \\
\hline Article Info \\
\hline Accepted: \\
04 June 2018 \\
Available Online: \\
10 July 2018 \\
\hline
\end{tabular}

A B S T R A C T

Powdery mildew caused by Oidium neolycopersici L. Kiss is one of the most important diseases of tomato under polyhouse conditions. During 2014-15, polyhouses of Kangra district (H.P., India) were surveyed and the disease severity was observed between 5.0 to 89.5 per cent affecting both quality and quantity of the harvest. Fourteen hybrids/cultivars of tomato were screened under p house conditions during 2014-15 cropping season, but all were found either susceptible or weakly resistant against powdery mildew. In vivo evaluation of bioagents viz., Trichoderma harzianum-1 (TH-1), T. harzianum-2 (TH-2), T. viride-1 (TV-1), T. viride-2 (TV-2) and Pseudomonas fluorescence-1 (PF-1) @ $10 \mathrm{~g} / 1$ showed 63.9-75.41 per cent disease control. Among these, both strains of T. harzianum (TH-1 and TH-2) were found highly effective in controlling the disease. In vivo evaluation of three botanicals viz., Eupatorium adenophorum, Melia azedarach and Azadirachta indica showed that aqueous extract at 100 per cent concentration provided more than 50 per cent disease control being maximum i.e. 65.1 per cent was provided by $E$. adenophorum. Three sprays of eight fungicides at 10 days interval were evaluated and hexaconazole 5EC @ $1 \mathrm{ml} / \mathrm{l}$ and difenoconazole 25EC @ $0.05 \mathrm{ml} / \mathrm{l}$ were found highly effective with 91.0 and 89.2 per cent disease control and 42.0 and 39.0 per cent increase in yield as compared to check, respectively.

\section{Introduction}

Tomato (Solanum lycopersicum L.) a member of Solanaceae family is one of the most popular and widely grown vegetables in the world after potato and stands top in the list of canned vegetables. Tomato plays a significant role in the economy of farmers of Himachal Pradesh. Year round cultivation of tomato can't be done in open fields due to inconsistent weather conditions and biotic factors which influence the production and quality of produce. In Himachal Pradesh, a hill state of India, protected cultivation is gaining importance and tomato as a cash crop is being cultivated throughout the year in polyhouses. Protected cultivation not only provides suitable and congenial microclimate for the crop production but, also for the development of various diseases. Among these, powdery 
mildew of tomato caused by Oidium neolycopersici L. Kiss is one of the most important diseases which reduce production and quality of the produce. The powdery mildew is a dangerous pathogen, which spread through temperate areas of the world and the disease can cause up to 50 per cent yield losses in tomato (Cerkauskas et al., 2011). The host range of the pathogen is broad and it is reported to attack over 60 species in 13 plant families, particularly members of Solanaceae and Curcubitaceae. (Jones et al., 2001). Powdery mildew of tomato caused by $O$. neolycopersici and $L$. taurica has been reported from United States (Kontaxis and Van 1978), Centeral valley (Campbell and Scheuerman 1979), Mexico (Sanchez 1983), Minidoka (Forster 1989), Korea (Woong et al., 1995), Iran (Banihashemi and Zakeri 1996), Florida (Marois et al., 2001), Bolivia (Correll et al., 2005), Venezuella (Montilla et al., 2007), Turkey (Yolageldi et al., 2008), China (Li et al., 2008) and Sebia (Stevanovic et al., 2012). In India, powdery mildew caused by $O$. neolycopersici was first time observed by Baiswar et al., (2009) on Solanum betaceum. Singh and Banyal (2015) observed powdery mildew of tomato as one of the most important disease under protected cultivation from Himachal Pradesh. L. taurica as a cause of powdery mildew of tomato was reported by Gupta et al., (2013) from Himachal Pradesh. Thomson and Jones (1981) reported 10-90 per cent yield loss in commercial tomato due to powdery mildew. Vallad et al., (2001) reported 50-60 per cent disease incidence and 50 per cent yield loss due to tomato powdery mildew caused by $O$. neolycopersici from Florida. Keeping all these aspects and increasing problem of tomato powdery mildew under protected cultivation in view, a survey was conducted in Kangra district of Himachal Pradesh during 2014-15 to know the status of powdery mildew. Polyhouses from farmer's field in Kangra district were surveyed and high disease severity was recorded from each of the polyhouses. Disease severity varied from 5.0 to 89.0 per cent and highest disease severity of 89 per cent was observed in Kunsal of Kangra district (Himachal Pradesh) with overall average disease severity accounting to 52 per cent. Since, there was no information available on the different aspects of management powdery mildew of tomato under protected cultivation from Himachal Pradesh and even from India, the study was designed for management of powdery mildew of tomato under protected cultivation with the objectives of evaluation of IDM components separately which included the usage of resistant cultivars/hybrids, biological antagonists and chemicals. In the present study, most commonly used cultivars, bioagents and fungicides in the region have been evaluated and it will provide resourceful information on possible management strategies in the region.

\section{Materials and Methods}

\section{Host resistance}

Fourteen hybrids/cultivars of tomato were screened under net house conditions during 2014-15 cropping season. Ten plants from each of the variety were transplanted to plots and were inoculated with challenge inoculum ( $<40$ conidia per microscopic field at $40 \mathrm{X}$ ) maintained in specially designed cages. Data on disease severity was recorded using scale 0-4 (Table 1) given by Toyoda (2008).

The data recorded on disease severity of different tomato hybrids/cultivars were further utilized for the calculation of Area Under Disease Progress Curve (AUDPC) and compared with the disease severity. The scale was converted to disease severity by using the formula

The AUDPC was calculated by using formula given by Shaner and Finney (1977). 
Where,

$$
\sum \frac{\left(y_{i}+y_{i+1}\right)}{2} t_{i+1}-t_{i}
$$

$\mathrm{y}_{\mathrm{i}}=$ disease severity at time $\mathrm{t}_{\mathrm{i}}$

$\mathrm{y}_{\mathrm{i}+1}=$ disease severity at time $t_{i+1}$

Disease severity index $(\%)=$

Sum of all disease ratings

Total no. of plants $\mathrm{x}$ maximum disease score

\section{Biological management}

\section{In vivo evaluation of botanicals}

To study the effect of botanicals as foliar spray for the management of powdery mildew of tomato, aqueous extract of three botanicals viz., Eupatorium adenophorum, Melia azedarach and Azadirachta indica were prepared and tested against the powdery mildew pathogen under net hose conditions in pots.

\section{Preparation of aqueous extract}

The aqueous extract was prepared by soaking $300 \mathrm{~g}$ of fine powder of each botanical (leaves) overnight in $600 \mathrm{ml}$ of sterilized distilled water $(1: 2 \mathrm{~W} / \mathrm{V})$ in $1000 \mathrm{ml}$ conical flask. Next day, the extract obtained was filtered through double layer of muslin cloth and twice through Whatman no. 1 filter paper to get clear filtrate. This was considered as standard aqueous extract for further dilutions (Sheo Raj Singh et al., 2007; Aditi, 2015). The plant extract were tested at 10, 25, 50, 75 and 100 per cent concentrations (Aditi, 2015). The aqueous extracts of botanicals were diluted in distilled water to get the desired concentrations. To study the effect of these botanical extract as foliar spray, an experiment was conducted in pots with four treatments replicated four times. In each replication, three pots were taken and each pot having two seedlings of 'Avtar' hybrid. Data on 18 tomato plants were recorded in each treatment. Three sprays of each bioagents were given at 10 days interval. First spray of extract was given on the appearance of disease in month of April and data on powdery mildew severity was recorded at 10 days interval. Plants sprayed with water served as control.

\section{In vivo evaluation of bioagents}

To study the efficacy of bioagents against tomato powdery mildew pathogen, five bioagents viz., Trichoderma harzianum-1 (TH1) T. viride-1 (TV-I) and Pseudomonas fluorescence (PF-I) from AAU, Anand, $T$. harzianum-2 (TH-2) and T. viride-2 (TV-2) from CSKHPKV were evaluated against powdery mildew of tomato in pots under net house conditions as foliar sprays at three doses i.e. $5,7.5$ and $10 \mathrm{~g} / \mathrm{l}\left(\mathrm{CFU}\right.$ of $1 \mathrm{X} 10^{6}$ to $1 \mathrm{X}$ $10^{8}$ ) (Aditi, 2015). The experiment was conducted in pots having six treatments replicated thrice. In each replication, three pots were taken and each pot having two seedlings of 'Avtar' hybrid. Data on 18 tomato plants were recorded in each treatment. The first spray of each bioagent was given on the first appearance of disease in the month of April and data on powdery mildew severity were recorded at 10 days interval. Three sprays of each bioagents were given at 10 days interval. Plants sprayed with water served as control.

\section{Chemical management}

To test the bioefficacy of fungicides against the disease, commonly used 8 fungicides were selected i.e. four systemic fungicides viz., hexaconazole 5EC (Contaf), triadiemefon 25WP (Bayleton), difenoconazole 25EC (Score) and Azoxysrobin 23EC (Mirador) and four non-systemic fungicides viz., dinocap 48EC (Karathane), mancozeb 75WP (Indofil), 
propineb 70WP (Antracol) and captan 50WP (Captan) were evaluated as foliar spray for the management of powdery mildew. An experiment was conducted in the polyhouse in Randomized Block Design (RBD) and all the treatments were replicated thrice. Seedlings of tomato hybrid 'Avtar' were transplanted in polyhouse during 2015-2016 with row $\times$ plant spacing of $60 \times 30 \mathrm{~cm}$. The first spray of fungicides was given on the first appearance of disease and data on powdery mildew disease severity were recorded before first spray and after 10 days of each spray. Data on 36 tomato plants (12 plants per replication) were recorded in each treatment. For foliar spray, each of the chemicals was evaluated individually by giving three sprays at 10 days interval.

\section{Statistical analysis}

The data recorded were subjected to statistical analysis wherever required. The differences exhibited by the treatments in various experiments were tested for their significance by employing CRD and RBD. All the data were analyzed by using CPCS-1 software.

\section{Results and Discussion}

The different IDM components i.e. evaluation of resistant cultivars, biological and chemical control were studied to manage the powdery mildew of tomato caused by $O$. neolycopersici.

Evaluation of tomato hybrids/cultivars for resistance against tomato powdery mildew

High disease severity i.e. 40- 65 per cent were observed in all the 14 tomato varieties /hybrids being minimum i.e. 40 per cent in Palam Tomato Hybrid-1 and Naveen and maximum i.e. 65 per cent disease severity was observed in Jyoti, Pusa Hybrid-1 and Him Sona.
Among all the hybrids/cultivars, 11 hybrids/cultivars were found susceptible having more than 50 per cent disease severity and three cultivars Palam Pride, Palam Tomato Hybrid-1 and Naveen were having less than 50 per cent disease severity and designated as Weakly Resistant (Table 2). The AUDPC value indicated that varieties having maximum disease severity i.e. 65 per cent in Jyoti, Pusa Hybrid-1 and Him Sona were also having maximum i.e. 805.0, 910.0 and 735.0 AUDPC value, respectively. The minimum value of AUDPC i.e. 409.5 was observed in both Palam Tomato Hybrid-1 and Naveen also having low disease severities. So, none of the evaluated hybrid/cultivar was found resistant against powdery mildew of tomato.

Li et al., (2008) while evaluating different tomato cultivars against powdery mildew found that all $L$. esculentum cultivars were susceptible while L. peruvianum LA 2172 and L. hirsutum G1.1560 were resistant. Singh et al., (2013) screened 17 varieties of tomato against powdery mildew and found only three varieties i.e. Punjab Chuhara, RCMT- 2 and Pant T-8 as completely resistant.

\section{Biological management}

\section{In vivo evaluation of bioagents against powdery mildew of tomato}

At $5.0 \mathrm{~g} / \mathrm{l}$, among all the tested bioagents, $T$. harzianum-1 was most effective and gave 32.0 per cent disease control followed by $T$. harzianum-2 which gave 29.1 per cent disease control over the check. At $7.5 \mathrm{~g} / 1$ also, $T$. harzianum-1 gave maximum disease control i.e. 50.1 per cent followed by $T$. harzianum-2 which gave 46.4 per cent disease control over check. However, at the concentration of 10.0 $\mathrm{g} / \mathrm{l}, \quad T$. harzianum-1 provided maximum disease control i.e. 75.4 per cent followed by T. harzianum-2 with non-significant difference and gave 71.1 per cent powdery 
mildew disease control over check. $P$. fluorescence-1 provided least but, good control of disease (63.9 per cent) among all the bioagents over the control (Table 3). Among all the bioagents, both strains of $T$. harzianum (TH-1 and $\mathrm{TH}-2$ ) were found highly effective i.e. more than 71 per cent disease control @ $10.0 \mathrm{~g} / \mathrm{l}$ and were statistically at par with each other. Both the strains of T. viride (TV-1 and TV-2) were also statistically at par in controlling powdery mildew of tomato and gave 66.7 to 68.3 per cent disease control, respectively. However, both the isolates of $T$. harzianum found to be the best among the tested bio agents against powdery mildew of tomato.

Kamal et al., (2007) reported Pseudomonas fluorescence as a good biocontrol agent in reducing powdery mildew of tomato. Velandia and Cotes (2007) found that formulated and unformulated prototype of Trichoderma koningii reduced tomato powdery mildew incidence and disease severity by $25-28$ per cent and 28- 66 per cent, respectively. AbdelKader et al., (2012) evaluated five bioagents against tomato powdery mildew and found that Trichoderma harzianum and Bacillus subtilis showed significant reduction in disease incidence of tomato powdery mildew as compared to other bioagents. Bucio villalabos and Martinez (2016) observed that C4 strain of $T$. harzianum among tested isolates gave better results when the formulation was sprayed on foliage in combination with drench to stem base against powdery mildew of tomato.

So, three sprays at 10 days of interval of all the tested bioagents at $10 \mathrm{~g} / \mathrm{l}$ found effective against powdery mildew of tomato.

\section{In vivo evaluation of botanicals against tomato powdery mildew}

Evaluation of botanicals against powdery mildew of tomato revealed that $E$. adenophorum was found to be highly effective under net house conditions. At 10 per cent concentration, E. adenophorum gave 6.3 per cent disease control among evaluated botanicals followed by $A$. indica and $M$. azedarach which gave 4.4 and 2.9 per cent disease control, respectively as compared to check (Table 4).

At 25,50 and 75 per cent concentrations, against tomato powdery mildew $E$. adenophorum gave high disease control i.e. 18.5, 53.5 and 58.8 per cent followed by $A$. indica which gave 9.7, 45.3 and 51.9 per cent over the check, respectively.

At 100 per cent concentration, $E$. adenophorum provided maximum i.e. 65 per cent disease control followed by $A$. indica with 57.0 per cent and minimum disease control i.e. 53.0 per cent was provided by $M$. azedarach as compared to check. However, all the three tested botanicals at 100 percent concentrations as 3 foliar sprays at 10 days interval gave more than 50 per cent tomato powdery mildew control and can be used in the disease management strategies. $E$. adenophorum at 100 per cent found to be the best among tested botanicals.

Naturally occurring biologically active compounds from plants are less hazardous than synthetic compounds. Szczech et al., (2000) found that brewery refuse extract was effective against tomato powdery mildew at 30, 60 and 100 per cent concentrations. Ko et al., (2003) evaluated seven oils and found high level of antifungal activity of sunflower oil against $O$. neolycopersici causing powdery mildew of tomato.

Sudha and Lakshman (2009) reported that leaf extract of Azadirachta indica (10 per cent) and bulb extract of Allium sativum and A. cepa (eight per cent) were highly effective against chili powdery mildew. 
Table.1 0-4 scale used for screening of tomato cultivars (Toyoda, 2008)

\begin{tabular}{|c|l|l|}
\hline Score & \multicolumn{1}{|c|}{ Visual observation } & \multicolumn{1}{|c|}{ Response } \\
\hline 0 & No visible pustule & Completely resistant \\
\hline 1 & Pustule with less than $10 \%$ leaf surface area & Moderately resistant \\
\hline 2 & Pustule with less than $50 \%$ leaf surface area & Weakly resistant \\
\hline 3 & Pustule with less than $75 \%$ leaf surface & Moderately Susceptible \\
\hline 4 & Pustule with more than $76 \%$ leaf surface area & Susceptible \\
\hline
\end{tabular}

Table.2 Evaluation of tomato hybrids/cultivars against Oidium neolycopersici

\begin{tabular}{|l|c|c|c|c|}
\hline Hybrid/Cultivar & $\begin{array}{c}\text { Per cent } \\
\text { Severity }\end{array}$ & Rating & $\begin{array}{c}\text { Reaction } \\
\text { Type }\end{array}$ & AUDPC \\
\hline Jyoti & 65 & 3 & S & 805.0 \\
\hline Pusa Hybrid-1 & 65 & 3 & S & 910.0 \\
\hline Him Sona & 65 & 3 & S & 735.0 \\
\hline K-21 & 62 & 3 & S & 686.0 \\
\hline R-21 & 62 & 3 & S & 661.5 \\
\hline P-21 & 60 & 3 & S & 679.0 \\
\hline S-22 & 60 & 3 & S & 707.0 \\
\hline Arshit & 60 & 3 & S & 672.0 \\
\hline Rakshita & 50 & 2 & S & 535.5 \\
\hline Palam Pink & 50 & 2 & MS & 518.0 \\
\hline Palam Pride & 48 & 2 & WR & 490.0 \\
\hline Palam Tomato Hybrid 1 & 40 & 2 & WR & 409.5 \\
\hline Naveen & 40 & 2 & WR & 409.5 \\
\hline Avtar & 60 & 3 & 731.5 \\
\hline WR- Weakl Resis & & & & \\
\hline
\end{tabular}

*WR- Weakly Resistant; MS- Moderately Susceptible; S-Susceptible. 
Table.3 In vivo evaluation of bioagents against $O$. neolycopersici causing powdery mildew of tomato

\begin{tabular}{|c|c|c|c|c|c|c|}
\hline \multirow[t]{2}{*}{ Bioagent } & \multicolumn{3}{|c|}{$\begin{array}{l}\text { Per cent disease severity at } \\
\text { different doses }(\mathrm{g} / \mathrm{l})^{*}\end{array}$} & \multicolumn{3}{|c|}{$\begin{array}{l}\text { Per cent disease control at } \\
\text { different doses }(\mathrm{g} / \mathrm{l})\end{array}$} \\
\hline & 5.0 & 7.5 & 10.0 & 5.0 & 7.5 & 10.0 \\
\hline $\begin{array}{l}\text { Trichoderma harzianum -1 } \\
\text { (TH-1) }\end{array}$ & $\begin{array}{c}31.3 \\
(34.0)\end{array}$ & $\begin{array}{c}23.3 \\
(28.8)\end{array}$ & $\begin{array}{c}11.3 \\
(19.6)\end{array}$ & 32.0 & 50.1 & 75.4 \\
\hline $\begin{array}{l}\text { Trichoderma harzianum - } 2 \\
\text { (TH-2) }\end{array}$ & $\begin{array}{c}32.6 \\
(34.8)\end{array}$ & $\begin{array}{c}25.0 \\
(29.9)\end{array}$ & $\begin{array}{l}13.0 \\
(21.1)\end{array}$ & 29.1 & 46.4 & 71.7 \\
\hline $\begin{array}{l}\text { Trichoderma viride }-1 \\
\text { (TV-1) }\end{array}$ & $\begin{array}{c}37.0 \\
(37.0)\end{array}$ & $\begin{array}{c}28.6 \\
(31.9)\end{array}$ & $\begin{array}{c}15.3 \\
(23.0)\end{array}$ & 19.5 & 38.7 & 66.7 \\
\hline $\begin{array}{l}\text { Trichoderma viride }-2 \\
\text { (TV-2) }\end{array}$ & $\begin{array}{c}34.6 \\
(36.0)\end{array}$ & $\begin{array}{c}28.0 \\
(32.3)\end{array}$ & $\begin{array}{c}14.6 \\
(22.5)\end{array}$ & 24.7 & 40.0 & 68.3 \\
\hline $\begin{array}{l}\text { Pseudomonas fluorescence } \\
\text { (PF-1) }\end{array}$ & $\begin{array}{c}38.7 \\
(38.4)\end{array}$ & $\begin{array}{c}30.0 \\
(33.2)\end{array}$ & $\begin{array}{l}16.6 \\
(24.1)\end{array}$ & 15.9 & 35.7 & 63.9 \\
\hline Control & $\begin{array}{c}46.0 \\
(42.7)\end{array}$ & $\begin{array}{c}46.7 \\
(43.1)\end{array}$ & $\begin{array}{c}46.0 \\
(42.7)\end{array}$ & - & - & - \\
\hline $\mathrm{CD}(\mathrm{p}=0.05)$ & 1.99 & 2.16 & 2.38 & - & - & - \\
\hline
\end{tabular}

*Figures within parentheses are arc sine transformed values

Table.4 In vivo evaluation of botanical against Oidium neolycopersici causing powdery mildew of tomato

\begin{tabular}{|c|c|c|c|c|c|c|c|c|c|c|}
\hline \multirow[t]{2}{*}{ Botanical } & \multicolumn{5}{|c|}{$\begin{array}{l}\text { Per cent disease severity at different } \\
\text { concentration* }\end{array}$} & \multicolumn{5}{|c|}{$\begin{array}{l}\text { Per cent disease control at different } \\
\text { concentration }\end{array}$} \\
\hline & 10 & 25 & 50 & 75 & 100 & 10 & 25 & 50 & 75 & 100 \\
\hline $\begin{array}{l}\text { Eupatorium } \\
\text { adenophorum }\end{array}$ & $\begin{array}{c}41.7 \\
(40.2)\end{array}$ & $\begin{array}{c}35.2 \\
(36.4)\end{array}$ & $\begin{array}{c}20.0 \\
(26.5)\end{array}$ & $\begin{array}{c}18.0 \\
(25.1)\end{array}$ & $\begin{array}{c}15.0 \\
(22.7)\end{array}$ & 6.3 & 18.5 & 53.5 & 58.8 & 65.1 \\
\hline $\begin{array}{l}\text { Melia } \\
\text { azedarach }\end{array}$ & $\begin{array}{c}43.2 \\
(41.1)\end{array}$ & $\begin{array}{c}40.0 \\
(39.2)\end{array}$ & $\begin{array}{c}24.7 \\
(29.8)\end{array}$ & $\begin{array}{c}23.0 \\
(28.6)\end{array}$ & $\begin{array}{c}20.2 \\
(26.7)\end{array}$ & 2.9 & 7.4 & 42.5 & 47.3 & 53.0 \\
\hline $\begin{array}{l}\text { Azadirachta } \\
\text { indica }\end{array}$ & $\begin{array}{c}42.5 \\
(40.7)\end{array}$ & $\begin{array}{c}39.0 \\
(38.6)\end{array}$ & $\begin{array}{c}23.5 \\
(29.0)\end{array}$ & $\begin{array}{c}21.0 \\
(27.2)\end{array}$ & $\begin{array}{c}18.5 \\
(27.2)\end{array}$ & 4.4 & 9.7 & 45.3 & 51.9 & 57.0 \\
\hline Control & $\begin{array}{c}44.5 \\
(41.8)\end{array}$ & $\begin{array}{c}43.2 \\
(41.2)\end{array}$ & $\begin{array}{c}43.0 \\
(40.9)\end{array}$ & $\begin{array}{c}43.7 \\
(41.4)\end{array}$ & $\begin{array}{c}43.0 \\
(40.9)\end{array}$ & - & - & - & - & - \\
\hline $\mathrm{CD}(\mathrm{p}=0.05)$ & 0.83 & 0.88 & 1.89 & 1.37 & 1.49 & - & - & - & - & 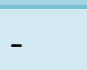 \\
\hline
\end{tabular}

*Figures within parentheses are arc sine transformed values 
Table.5 Fungicidal management of powdery mildew of tomato under protected cultivation

\begin{tabular}{|c|c|c|c|c|c|c|c|}
\hline \multirow[t]{2}{*}{ Fungicide } & \multirow[t]{2}{*}{$\begin{array}{c}\text { Dose } \\
(\%)\end{array}$} & \multicolumn{3}{|c|}{$\begin{array}{c}\% \text { disease severity } \\
\text { after } 10 \text { days* }\end{array}$} & \multirow{2}{*}{$\begin{array}{c}\% \text { Disease } \\
\text { control after } \\
3^{\text {rd }} \text { spray }\end{array}$} & \multicolumn{2}{|c|}{ Yield } \\
\hline & & $\begin{array}{c}1^{\text {st }} \\
\text { spray }\end{array}$ & $\begin{array}{c}2^{\text {nd }} \\
\text { spray }\end{array}$ & $\begin{array}{c}3^{\text {rd }} \\
\text { spray }\end{array}$ & & $\begin{array}{c}\text { Yield } \\
\left(\mathrm{q} / \mathbf{1 0 0} \mathrm{m}^{2}\right)\end{array}$ & $\begin{array}{l}\% \text { Yield } \\
\text { increase }\end{array}$ \\
\hline $\begin{array}{l}\text { Hexaconazole } 5 \\
\text { EC }\end{array}$ & 0.10 & $\begin{array}{c}23.3 \\
(28.8)\end{array}$ & $\begin{array}{c}17.6 \\
(24.8)\end{array}$ & $\begin{array}{c}7.4 \\
(15.8)\end{array}$ & 91.0 & $\begin{array}{c}13.8 \\
(21.8)\end{array}$ & 42.0 \\
\hline $\begin{array}{l}\text { Triadimefon } 25 \\
\text { WP }\end{array}$ & 0.05 & $\begin{array}{c}28.3 \\
(32.1)\end{array}$ & $\begin{array}{c}22.8 \\
(28.5)\end{array}$ & $\begin{array}{c}11.1 \\
(19.5)\end{array}$ & 86.0 & $\begin{array}{c}13.0 \\
(21.4)\end{array}$ & 34.0 \\
\hline $\begin{array}{l}\text { Difenoconazole } 25 \\
\text { EC }\end{array}$ & 0.05 & $\begin{array}{c}25.3 \\
(30.2)\end{array}$ & $\begin{array}{c}19.2 \\
(25.9)\end{array}$ & $\begin{array}{c}8.5 \\
(16.9)\end{array}$ & 89.2 & $\begin{array}{c}13.5 \\
(21.5)\end{array}$ & 39.2 \\
\hline $\begin{array}{l}\text { Azoxystrobin } 23 \\
\text { EC }\end{array}$ & 0.10 & $\begin{array}{c}31.7 \\
(34.2)\end{array}$ & $\begin{array}{c}33.4 \\
(35.3)\end{array}$ & $\begin{array}{r}48.4 \\
(44.1)\end{array}$ & 39.0 & $\begin{array}{c}11.5 \\
(19.8)\end{array}$ & 17.9 \\
\hline Dinocap 48EC & 0.10 & $\begin{array}{c}28.4 \\
(32.2)\end{array}$ & $\begin{array}{c}23.1 \\
(28.7)\end{array}$ & $\begin{array}{c}11.3 \\
(19.6)\end{array}$ & 85.7 & $\begin{array}{c}12.8 \\
(20.9)\end{array}$ & 32.1 \\
\hline Mancozeb 75WP & 0.25 & $\begin{array}{c}32.2 \\
(34.6)\end{array}$ & $\begin{array}{c}34.7 \\
(36.0)\end{array}$ & $\begin{array}{c}49.5 \\
(44.7)\end{array}$ & 37.5 & $\begin{array}{c}11.3 \\
(19.6)\end{array}$ & 16.0 \\
\hline Propinenb 70WP & 0.25 & $\begin{array}{c}32.5 \\
(34.6)\end{array}$ & $\begin{array}{c}37.2 \\
(37.6)\end{array}$ & $\begin{array}{c}60.9 \\
(51.3)\end{array}$ & 23.1 & $\begin{array}{c}10.4 \\
(18.8)\end{array}$ & 6.8 \\
\hline Captan 50WP & 0.30 & $\begin{array}{c}32.8 \\
(34.9)\end{array}$ & $\begin{array}{c}38.8 \\
(38.5)\end{array}$ & $\begin{array}{c}63.9 \\
(53.0)\end{array}$ & 19.3 & $\begin{array}{c}9.9 \\
(18.4)\end{array}$ & 1.8 \\
\hline Control & - & $\begin{array}{c}37.4 \\
(37.7)\end{array}$ & $\begin{array}{c}49.4 \\
(44.6)\end{array}$ & $\begin{array}{c}79.2 \\
(62.9)\end{array}$ & - & $\begin{array}{c}9.7 \\
(18.1)\end{array}$ & - \\
\hline$C D(p=0.05)$ & - & 1.83 & 2.05 & 2.23 & - & 0.36 & - \\
\hline
\end{tabular}

* Figures within parentheses are arc sine transformed values

\section{Chemical management}

Data recorded from the evaluation of chemicals (Table 5) indicated that out of eight fungicides tested, three sprays of hexaconazole 5 EC @ $1 \mathrm{ml} / \mathrm{l}$ was most effective and gave 91.0 percent disease control with 42.0 per cent increase in yield, followed by difenoconazole 25EC @ $0.5 \mathrm{ml} / \mathrm{l}$ which gave 89.2 per cent disease control with 39.2 per cent increase in yield over the check and statistically at par with hexaconazole 5EC. Triadimefon 25WP @ $0.5 \mathrm{~g} / \mathrm{l}$ and dinocap 48EC @ $1 \mathrm{ml} / \mathrm{l}$ were also found effective for the management of powdery mildew of tomato and provided 86.0 and 85.7 per cent disease control with 34.0 and 32.1 per cent increase in yield over control, 
respectively, under protected cultivation. Statistically, dinocap 48EC was at par with triadimefon 25WP.

Among systemic fungicides, azoxystrobin 23EC@1 ml/l was found to be least effective with 39.0 per cent disease control and 17.9 per cent increase in yield and statistically at par with non systemic fungicide i.e. mancozeb 75WP @ $2.5 \mathrm{~g} / \mathrm{l}$ which provided 37.5 per cent disease control and 16.0 per cent increase in yield as compared to check. propineb 70WP @2.5 g/l was found also found less effective with 23 per cent disease control and 68 per cent increase in yield as compare to control.

Among all the fungicides, captan 50WP @ 3 $\mathrm{g} / \mathrm{l}$ was least effective in controlling powdery mildew of tomato under protected cultivation provided only 19.3 per cent disease control with 1.8 per cent increase in yield as compared to check. During the study, it was also observed that the disease severity gradually decreased from initial disease severity with sprays of hexaconazole 5EC (23.3-7.4 per cent), triadimefon 25WP (28.311.1 per cent), difenoconazole 25EC (25.3-8.4 per cent) and dinocap 48EC (28.4-11.3 per cent), however, it was increased in other fungicide i.e. azoxystrobin 23EC (31.7-48.4 per cent), mancozeb 75WP (32.2-63.9 per cent), propineb 70WP (32.5-60.9 per cent) and captan 50WP (32.8-63.9 per cent) but, less as compared to check.

Hence, it was observed that three sprays at 10 days interval of hexaconazole 5EC @ $1 \mathrm{ml} / \mathrm{l}$ or difenconazole 25EC @ $0.5 \mathrm{ml} / \mathrm{l}$ were highly effective for the management of tomato powdery mildew. Triadimefon 25WP @ $0.5 \mathrm{~g} / \mathrm{l}$ and dinocap 48EC @ $1 \mathrm{ml} / \mathrm{l}$ were also found effective and can be used in the management of disease. However, hexaconazole EC was found best. Maximum tomato powdery mildew control and increase in the fruit yield was obtained with three sprays of Score (difenoconazole), followed by Tilt (propiconazole), Contaf (hexaconazole) and Folicur (tebuconazole) (Anonymous 2013).

Hooda et al., (2011) found that out of IPM, Chemical and organic modules, there was significant yield enhancement in chemical and IPM modules compared to purely organic module against major pests and diseases of tomato. Cerkauskas and Brown (2015) reported Acibenzolar-5-methyl, trifloxystrobin, azoxystrobin, sulfur and JMSstylet oil were effective in controlling powdery mildew of tomato.

In conclusion, none of the evaluated 14 tomato hybrid/cultivar was found resistant against the powdery mildew disease. Foliar sprays of tested bioagents $(10 \mathrm{~g} / \mathrm{l})$ and botanicals $(100 \%)$ were found very effective in the management of the disease. Both the strains of $T$. harzianum (TH-1 and $\mathrm{TH}-2)$ were highly effective and gave 75.4 and 71.7 per cent disease control at $10 \mathrm{~g} / \mathrm{l}$, respectively. E. adenophorum was highly effective and gave 65.1 per cent disease control at 100 per cent concentration followed by $A$. indica which gave 57.0 per cent disease control among the tested botanicals. However, least but good disease control (53.0\%) was also provided by $M$. azedarach. Three sprays at 10 days interval of hexaconazole 5EC @ $1 \mathrm{ml} / \mathrm{l}$ or difenoconazole 25EC @ $0.5 \mathrm{ml} / \mathrm{l}$ were highly effective for the management of powdery mildew of tomato.

Overall, three sprays of bioagents at $10 \mathrm{~g} / \mathrm{l}$ and botanicals at100 per cent concentration from the onset of first appearance of symptom or spray of hexaconazole 5EC @ $1 \mathrm{ml} / \mathrm{l}$ found to be the best suggested for effectively managing the tomato powdery mildew. 


\section{References}

Abdel-Kader, M.M., El-Mougy, N.S., Aly, M.D.E., Lashin, S.M. and Abdel-Kareem, F., (2012). Greenhouse biological approach for controlling foliar diseases of some vegetables. Adv. Lif. Sci., 2: 98-103

Aditi, K.M., (2015). Epidemiology and management of gray mould of capsicum under protected cultivation. M.Sc thesis, CSK HPKV, Palampur. pp 30-32.

Anonymous., (2013). Annual Progress Report 2012-13. Deptt of Plant Pathology. CSK HPKV Palampur. 81p

Baiswar, P., Braun, U., Chandra, S. and Ngachan, S.V., (2009). First report of an Oidium sp. [neolycopersici] on Solanum betaceum in India. Australas. Plant Dis. Notes., 4: 3233

Banihashemi, Z., and Zakeri, Z., (1996). The occurrence of Leveillula taurica on tomato and pepper in Iran. Iran. J. Plant Pathol., 32: 27-28

Bucio-Villalobos, C.M., Martinez- Jaime, O.A. (2016). Effect of drench to stem base and foliage spray with Trichoderma harzianum on powdery mildew disease (Leveillula taurica) in macrotunnel-grown tomato. Indian. Phytopath., 69(4): 409411

Campbell, R.N., and Scheuerman, R.W., (1979). Oidiopsis taurica on processing tomatoes in the central valley of California. Plant Dis Rep., 63: 1087

Cerkauskas, R.F., and Brown, J., (2015). Aspects of the epidemiology and control of powdery mildew (Oidium neolycopersici) on tomato in Ontario, Canada. Can.J. Plant. Pathol., 37: 448-464

Cerkauskas, R.F., Ferguson, G., and Banik, M., (2011). Powdery mildew (Leveillula taurica) on greenhouse and field peppers in Ontario-host range, cultivar response and disease management strategies. Can. J. Plant. Pathol., 33: 485-498

Correll, J.C., Villarroel, M.I., McLeod, P.J., Cazon, M.I. and Rivadeneria, C., (2005). First report of powdery mildew caused by Leveillula taurica on tomato and pepper in Bolivia. Plant Dis., 89: 776

Forster, R.L., (1989). Powdery mildew of greenhouse cucumbers and tomatoes caused by Leveillula taurica in Idaho. Plant Dis., 73: 1020

Gupta, M., Kumar, R., Bharat, N., Bhardwaj,. and Kumar, M., (2013). Occurrence of powdery mildew caused by Leveillula taurica in organically produced tomatoes. ISAAA (International Service for the Acquisition of Agri-Biotech Applications SE Asia Center) Varanasi, India

Hooda, K.S., Sushil, S.N., Joshi, D., Bhatt, J.C., Hedau, N.K., and Gupta, H.S., (2011). Efficacy of different modules for the management of major pests of tomato (Lycopersicum esculentum) and garden pea (Pisum sativum) in Himalayas. Indian. Phytopath., 64(4): 335-341

Jones, H., Whipps, J.M., and Gurr, S.J., (2001). Tomato powdery mildew fungus Oidium neolycopersici. Mol. Plant. Pathol., 2: 303-309

Kamal, S., Kumar, R., Raghav, M. and Singh, R.V., (2007). Field efficacy of bioagents and fungicides against tomato (Lycopersicon esculentum. Mill) diseases. Environ. Ecol., 25: 921-924

Ko, W.H., Wang, S.Y., and Hsieh, T.F., (2003). Effects of sunflower oil on tomato powdery mildew caused by Oidium neolycopersici. J. Phytopathol., 15: 144148

Kontaxis, D.G., and Van, M.A., (1978). Powdery mildew of tomato - a new disease in the United States. Plant. Dis. Rep., 62: 892893

Li, C.W., Pei, D.L., Wang, W.J., Ma, Y.S., Wang, L., Wang, F., Liu, J.L., and Zhu, W.M., (2008). First report of powdery mildew caused by Oidium neolycopersici on tomato in China. Plant. Dis., 92: 1370

Marois, J.J., Momol, M.T., Kimbrough, J.W., Hochmuth, R.C., and Dankers, W., (2001). First report of powdery mildew on greenhouse tomatoes caused by Oidium neolycopersici in Florida. Plant Dis., 85: 1292

Montilla, J.O., Gonzalez, M.S., and Renaud, D., (2007). First report of powdery mildew on tomato caused by Oidium neolycopersici in Venezuela. Plant Dis., 91: 910

Sanchez, C.M.A., (1983). La cenicilladel tomate 
causada por Oidiopsis taurica (Lev) Salmon Una nuevaenfermedaden el estado de Sinaloa. Rev.Mex. Fitopatol., 2: 3-6

Shaner, G., and Finney, R.E., (1977). The effect of nitrogen fertilization on the expression of slow mildewing resistance in Knox wheat. Phytopath., 67: 1051-1056

Sheo Raj Singh., Praja Pati, R.K., Srivastava, S.S.L., Pandey, R.K., and Gupta, P.K., (2007) Evaluation of different botanicals and non-target pesticides against Sclerotium rolfsii causing collar rot of lentil. Indian Phytopath., 60 (4): 499-501

Singh, A., and Banyal, D.K., (2015). Occurrence of different diseases of capsicum, tomato and cucumber under protected cultivation in Himachal Pradesh. Plant Dis Res., 26: 187

Singh, A.K., Singh, S.K., and Bhushan, A., (2013). Evaluation of tomato (Lycopersicon esculentum Mill.) cultivars/lines against multiple diseases under intermediate hill conditions of Jammu \& Kashmir. J. Mycopathol. Res., 51: 193-194

Stevanovic, M., Stankovic, I., Vucurovic, A., Dolovac, N., Pfaf-Dolovac, E., Krstic, B., and Bulajic, A., 2012. First report of Oidium neolycopersici on greenhouse tomatoes in Serbia. Plant Dis., 96: 912

Sudha, A., and Lakshmanan, P., (2009). Integrated disease management of powdery mildew (Leveillula taurica (Lev.) Arn.) of Chilli (Capsicum annuum L.). Arch. Phytopath. Plant Prot., 42:
299-317

Szczech, M., Dyki, B., and Sobolewski, J., (2000). Efficacy of brewery refuse extract against tomato powdery mildew (Oidium lycopersicum). Veg. Crop. Res. Bull., 53: 65-73

Thomson, S.V., and Jones, W.B., (1981). An epiphytotics of Leveillula taurica on tomatoes in Utah. Plant dis., 65: 518-519

Toyoda, H., (2008). An inoculation assay of tomato plants for screening resistance to Oidium neolycopersici: Tabulation of host responses and fungal growth on laboratory list of common and wild Lycopersicon species. Mem.Fac. Agric. Kagoshima. Univ., 41: 177-188

Vallad, G., Roberts, P., and Momol, T., (2001). Powdery Mildew on Tomato http://edis.ifas.ufl.edu.

Velandia, C.A.M., and Cotes,. A.M., (2007). Survival in the phylloplane of Trichoderma koningii and biocontrol activity against tomato foliar pathogens. Bulletin OILB/SROP., 30: 557-561

Woong, K.S., Hyeuk, K.J., Kyo, S.W., and Kyu, K.H., (1995). Occurrence of powdery mildew on tomato caused by Oidiopsis taurica (Lev.) Arnaud (Leveillula taurica) in Korea. Kor. J. Plant Pathol., 11: 380382

Yolageldi, L., Sin, B., and Onogur, E., (2008). First report of Oidium neolycopersici on tomatoes in Turkey. Plant Pathol., 57: 373.

\section{How to cite this article:}

Arushi, A.B. Malannavar and Banyal, D.K. 2018. Evaluation of IDM Components for Management of Tomato Powdery Mildew under Protected Cultivation. Int.J.Curr.Microbiol.App.Sci. 7(07): 21-31. doi: https://doi.org/10.20546/ijcmas.2018.707.003 